\title{
Endometrial assessment in cases of primary infertility in women: a prospective study
}

\author{
Soumya R. Patil ${ }^{1}$, Rajesh Patil ${ }^{2 *}$
}

\begin{abstract}
${ }^{1}$ Department of Obstetrics and Gynecology, Gulbarga Institute Medical Sciences, Kalaburagi, Karnataka, India
${ }^{2}$ Department of Pathology, Mahadevappa Rampure Medical College, Kalaburagi, Karnataka, India
\end{abstract}

Received: 20 October 2019

Revised: 21 December 2019

Accepted: 27 December 2019

\author{
*Correspondence: \\ Dr. Rajesh Patil, \\ E-mail: drrajeshpatil007@gmail.com
}

Copyright: () the author(s), publisher and licensee Medip Academy. This is an open-access article distributed under the terms of the Creative Commons Attribution Non-Commercial License, which permits unrestricted non-commercial use, distribution, and reproduction in any medium, provided the original work is properly cited.

\begin{abstract}
Background: Worldwide Infertility rate prevails around $8-12 \%$ of all couples; approximately 80 million are infertile. In India $10-15 \%$ of couples are infertile. Investigating for infertility is to intervene into the modifiable/treatable causes. Therefore, the present study has been undertaken to investigate the morphological patterns of endometrial tissue in women with primary infertility.

Methods: The study included 60 cases with complaints of infertility (primary). The premenstrual D and C was done to obtain endometrial biopsy. The present prospective study was a descriptive study and the values are mentioned in percentages.

Results: In present study a total of 60 cases were studied. Out of which 36 cases $(60 \%)$ belonged to the young adult age group. The predominant morphological pattern was that of secretory endometrium seen in 22 cases (36.66\%) as opposed to proliferative, endometritic or tubercular pattern. The predominant menstrual pattern recorded was regular; seen in 41 cases $(68.33 \%)$ as opposed to irregular or mennorhagic patterns.

Conclusions: The endometrial biopsy has a great role in screening the cases of infertility as it helps to assess the information about ovulation, ripening of the endometrial tissue and other abnormal endometrial reaction, hormonal imbalance. This is the only method to label the diagnosis of endometrial tuberculosis in an apparently healthy female.
\end{abstract}

Keywords: Biopsy, Curettage, Dilatation, Endometrial, Infertility patterns, Pre-menstrual

\section{INTRODUCTION}

Infertility is defined as the inability to conceive after one year of unprotected coitus. ${ }^{1}$ Primary infertility is defined as the failure to conceive at all. Worldwide Infertility rate prevails around $8-12 \%$ of all couples, approximately 80 million are infertile. In India $10-15 \%$ of couples are infertile. The magnitude of the problem of infertility varies from place to place, country to country and is also the concern of infertile couple. The current problems contributing to infertility are delayed child bearing to achieve acceptable socio-economic status; educational and professional needs. Investigating for infertility is to intervene into the modifiable/treatable causes. ${ }^{1-3}$ Endometrial biopsy with routine hematoxylin and eosin staining is an important simple investigation because endometrial biopsy can be practiced in developing countries like India, where complex expensive immunological and hormone assay procedures are not easily available and/or affordable. Therefore, the present study was undertaken to investigate the morphological patterns of endometrium in infertile women. 


\section{METHODS}

The present prospective study was carried out in the department of obstetrics and gynecology and pathology of Govt. Institute of Medical Science, Kalaburagi, after the ethical approval from the Institutional Ethics Committee.

\section{Inclusion criteria}

- The study included 60 cases with complaints of infertility (primary) in the time period from January 2018 to January 2019. Patients who failed to conceive after one year of unprotected sex following marriage were investigated as cases of primary infertility.

\section{Exclusion criteria}

- The exclusion criteria's were infertility within one year of marriage, non-co-operative patients and male factors causing infertility.

Clinical details in the form of menstrual cycle, last menstrual period (LMP), age at marriage and obstetric history were obtained. The procedure of dilatation and Curettage (D and C) was explained and informed consent was taken. The premenstrual $\mathrm{D}$ and $\mathrm{C}$ was done to obtain endometrial biopsy. $\mathrm{D}$ and $\mathrm{C}$ was done any time in cases of Amenorrhea and prolonged bleeding. The endometrial tissue was fixed in $10 \%$ formalin for 24 hours and routinely processed. 5-6 micron this section were cut and performed hematoxylin and eosin stain for morphology of endometrium and dating of endometrium (Noye's method) and Ziehl-Neelsen (ZN) stain for acid fast bacilli in all suspected cases. The present prospective study was a descriptive study and the values are mentioned in percentages.

\section{RESULTS}

In present study a total of 60 cases were studied. Study included various morphological patterns of endometrium in infertility patients belonging to secretory phase, proliferative phase and hyperplasia were documented in the present study. The youngest patient seen was 21 years old and eldest was 38 years in primary infertility cases with an average age of 26.9 years (Table 1). In primary infertility group maximum cases $36(60 \%)$ belonged to the age group of 18-25 years.

Table 1: Age group wise distribution of primary and secondary infertility patients.

\begin{tabular}{|llllll|}
\hline Type of infertility & Number $(\%)$ & Age group & & & \\
& & $\mathbf{1 8 - 2 5}$ & $\mathbf{2 5 - 3 0}$ & $\mathbf{3 0 - 3 5}$ & $\mathbf{3 5 - 4 0}$ \\
\hline Primary & $60(78.95 \%)$ & $36(60 \%)$ & $19(31.66 \%)$ & $4(6.66 \%)$ & $1(1.66 \%)$ \\
\hline
\end{tabular}

Table 2: Morphological patterns of endometrium.

\begin{tabular}{|lll|}
\hline \multirow{2}{*}{ Type of endometrium } & \multicolumn{2}{l|}{ Primary infertility } \\
\hline Secretory & No. & Percentage \\
\hline Proliferative & 22 & $36.66 \%$ \\
\hline Tubercular & 20 & $33.33 \%$ \\
\hline Cystic hyperplasia & 2 & $3.33 \%$ \\
\hline Polyp & 8 & $13.33 \%$ \\
\hline Nonspecific endometritis & 4 & $6.66 \%$ \\
\hline Total & 4 & $6.66 \%$ \\
\hline
\end{tabular}

Authors observed various patterns of endometrium in primary infertility like secretory phase (36.66\%), proliferative (anovulatory) endometrium was seen in $(33.33 \%)$, tubercular $(3.33 \%)$, CGH $(13.33 \%)$, polyp $(6.66 \%)$, and nonspecific endometritis $(6.66 \%)$ (Table 2$)$. Various menstrual pattern was recorded (Table 3). Regular menstrual cycles were seen in majority of patients.

The dating of endometrium was done for diagnosis of luteal phase defect as per Noye's criteria. The diagnosis of LPD was made as directed by Jones criteria which considers LPD as a lag by two or more than two days in the histological development of the endometrium.

Various menstrual pattern was recorded. Regular menstrual cycles were seen in majority of patients.

Table 3: Menstrual patterns of endometrium in primary and secondary infertility.

\begin{tabular}{|ll|}
\hline Type of menstruation & Primary infertility \\
\hline Regular & 41 \\
\hline Irregular & 8 \\
\hline menorrhagia & 2 \\
\hline polymenohhagia & 2 \\
\hline Secondary amenorrhea & 2 \\
\hline Poly menorrhagia & 5 \\
\hline Total & $\mathbf{6 0}(\mathbf{1 0 0 \%})$ \\
\hline
\end{tabular}

\section{DISCUSSION}

The cause of infertility may be difficult to determine but may include inadequate levels of certain hormones in both men and women, and trouble with ovulation in women. The simple and most accurate assessment of 
endometrium and ovulation can be done by endometrial evaluation. The secretory phase endometrium in premenstrual biopsy indicates that the cycle is ovulatory and indirectly rules out all the cause of infertility related to ovulation. Earlier, basal body temperature was used to confirm the ovulation.

Table 4: Comparison of various types of infertility with other studies.

\begin{tabular}{|llll|}
$\begin{array}{l}\text { Type of } \\
\text { infertility }\end{array}$ & $\begin{array}{l}\text { Present } \\
\text { study }\end{array}$ & $\begin{array}{l}\text { Abbasi N } \\
\text { et al }\end{array}$ & $\begin{array}{l}\text { Nandedkar } \\
\text { SS et al }\end{array}$ \\
\hline Primary & $60(78.95 \%)$ & $447(89 \%)$ & $1841(80.11 \%)$ \\
\hline
\end{tabular}

Endometrial biopsy will give an opportunity to directly evaluate the target tissue and can assess the hormonal status, ovulation, regular ripening of the endometrium, abnormal endometrial reaction due to hormonal imbalance and diagnose some endometrial pathologies causing infertility. ${ }^{5}$ Many studies highlighted the endometrial biopsy assessment is safe, easy and costeffective means of assessment of endometrial maturation, confirmation of ovulatory cycle and assessment of corpus luteum adequacy. In a study by Ross GT et al 15-20\% of all infertile women have demonstrable functional and anatomical endometrial disturbances. Endometrial tissue is important in nidation of young fertilized ovum8. In Indian studies by Shetty V, Sillo-Seidl G, and Abbasi N et al showed similar pattern, causes, and age group distribution (Tables 4 and 5). In few studies' glycogen and alkaline phosphatase content of the endometrium and stated that the biochemical changes run parallel to the histological changes that authors commonly observe in the endometrium.

Table 5: Comparison of various Indian studies.

\begin{tabular}{|lllll|}
\hline Type of endometrium & Present study & Shetty V & Sillo-Seidl G & Abbasi N et al $^{\mathbf{6}}$ \\
\hline Secretory & $36.66 \%$ & $72.54 \%$ & $56 \%$ & $71 \%$ \\
\hline Proliferative & $33.33 \%$ & $24.5 \%$ & $30 \%$ & $23 \%$ \\
\hline Tubercular & $3.33 \%$ & & & $4 \%$ \\
\hline Cystic hyperplasia & $13.33 \%$ & & & \\
\hline Polyp & $6.66 \%$ & & & \\
\hline Nonspecific endometritis & $6.66 \%$ & & & \\
\hline Total & $\mathbf{1 0 0 \%}$ & & & \\
\hline
\end{tabular}

\section{CONCLUSION}

Endometrial biopsy has a great role in cases of screening the infertility as it helps to assess the information about ovulation, ripening of the endometrium and other abnormal endometrial reaction, hormonal imbalances. This is the only method to label the diagnosis of endometrial tuberculosis in an apparently healthy female.

\section{Funding: No funding sources}

Conflict of interest: None declared

Ethical approval: The study was approved by the Institutional Ethics Committee

\section{REFERENCES}

1. Berek JS, Rinehart RD, Hillard PA, Adashi EY. Novak's Gynaecology, Lippincott Williams and Wilkins, $13^{\text {th }}$ ed; 2002.

2. Bhatia N. Updated and revised Jeffcoate's. Principles of Gynaecology International edition. Arnold Publishers (London, New Delhi); 2001.
3. Padubidri VG, Daftary SN, Shaw's text book of Gynaecology, $13^{\text {th }}$ ed, Reed Elsevier India Pvt. Ltd; 1998.

4. Shetty V. Endometrium in subfertility: a histochemical study. J Obst Gyncol India. 1959;10:139-41.

5. Sillo-Seidl G. The analysis of the endometrium of 1000 sterile women. J Obst Gyncol India. 1971;21(46):462-6.

6. Abbasi N, Tyagi SP, Saxena K, Hameed S. histopathological study of endometrium in infertile women. J Obst Gyncol India. 1977;27:376-82.

7. Nandedkar SS, Patidar E, Gada DB, Malukani K, Munjal K, Varma A. Histomorphological Patterns of endometrium in infertility. J Obstet Gynaecol India. 2015;65(5):328-34.

8. Ross GT, Cargille CM, Lipsett MB, Rayford PL, Marshall JR, Strott CA, et al. Pituitary and gonadal hormones in women during spontaneous and induced ovulatory cycles. Recent Prog Horm Res. 1970;26:14.

Cite this article as: Patil SR, Patil R. Endometrial assessment in cases of primary infertility in women: a prospective study. Int J Reprod Contracept Obstet Gynecol 2020;9:580-2. 